\title{
Modeling the civil servant discipline in Indonesia: partial least square-structural equation modeling approach
}

\author{
Nur F. Soelaiman ${ }^{1 *}$, Sharifah S. S. Ahmad ${ }^{1}$, Othman Mohd ${ }^{1}$, Rosyid R. Al Hakim ${ }^{2,3,4}$, Hexa A. \\ Hidayah $^{5}$ \\ ${ }^{1}$ Faculty of Information and Communication Technology, Universiti Teknikal Malaysia Melaka, Malaysia \\ ${ }^{2}$ Faculty of Engineering and Computer Science, Jakarta Global University, Indonesia \\ ${ }^{3}$ Graduate School, IPB University, Indonesia \\ ${ }^{4}$ School of Computer Science, Nusa Putra University, Indonesia \\ ${ }^{5}$ Faculty of Biology, Universitas Jenderal Soedirman, Indonesia \\ Email: *nfauz1@yahoo.com \\ doi.org/10.54099/aijb.v1i1.72
}

\begin{tabular}{|c|c|}
\hline ARTICLE INFO & ABSTRACT \\
\hline $\begin{array}{l}\text { Article history: } \\
\text { Received: January 20, } 2022 \\
\text { Revised: January 26, } 2022 \\
\text { Accepted: January 27, } 2022\end{array}$ & $\begin{array}{l}\text { Purpose - This paper seeks to discover the factors that influence the } \\
\text { supervisor to give the punishment level to civil servant staff - the data being } \\
\text { used is a questionnaire to several civil servants in public academic } \\
\text { institutions. } \\
\text { Methodology/approach - This research used computational tools to } \\
\text { classify transgressions into punishment categories (light, medium, or } \\
\text { severe) with the model using the data science technique based on the partial } \\
\text { least square-structural equation modeling (PLS-SEM) approach. } \\
\text { Findings - It was found that the model of civil servant discipline in } \\
\text { Indonesia is based on } 14 \text { hypotheses from bootstrapping technique and by } \\
\text { using data science technique to support the result analysis of PLS-SEM. } \\
\text { Novelty/value - This research contributed to providing civil servant } \\
\text { supervisors to understand factors that influence the discipline of their staff, } \\
\text { so it can be used to determine the punishment categorization. }\end{array}$ \\
\hline
\end{tabular}

This work is licensed under a Creative Commons Attribution-NonCommercial 4.0 International License.

\section{INTRODUCTION}

Indonesia has approximately 3.74 million civil servants, or 1.3 percent of the 2010 population (Tjiptoherijanto, 2012). The civil servant population in Indonesia has grown over time since the colonialization period. Around 50,000 persons were employed in the civil service at the end of the Dutch colonial rule, 4.6 million in 2012 (Tjiptoherijanto, 2012). The number of civil servants is separated into various government or departments offices, moreover divided into five layers of government: Central, Provinces, Kabupaten (Districts) and Kota (Municipalities or City), Kecamatan (Sub-districts), and Kelurahan/Desa (Villages) (Nasution, 2016). In 2013, there were 34 provinces, 413 districts, 98 municipalities, 9.982 subdistricts, and 80.414 villages administrative government in Indonesia (Nasution, 2016). In Indonesia, many civil servants should be catered to well by the government to manifest working efficiency and effectiveness (Pratama et al., 2015). Every single country has implemented civil servant discipline to its employees, like in the United States (Ujhelyi, 
Soelaiman et al.: Modeling the civil servant discipline in Indonesia: partial least square-structural equation modeling approach

2014), Malaysia (Division for Public Administration and Development Management, 2005), and Indonesia (Presiden Republik Indonesia, 2010). The last-mentioned country has implemented Government Regulation No. 532010 (PP53) to manage civil servants in Indonesia.

Indonesia Government Regulation No. 532010 (PP53) is a regulation concerning the discipline of civil servants that must be obeyed and implemented by all employees (Presiden Republik Indonesia, 2010). If employees make mistakes or take actions that do not comply with PP53, they will be processed and punished (Presiden Republik Indonesia, 2010). In PP53, several types of penalties will be given, such as warnings, reprimands, fines and deductions, suspensions, transfers, and dismissals (Presiden Republik Indonesia, 2010). There are three levels of disciplinary punishment: light punishment, medium punishment, and severe punishment (Presiden Republik Indonesia, 2010). The institution has also widely implemented government regulation similar to in central government. Most violations in districts, municipalities, sub-districts, and villages are in light punishment. The case of medium and severe punishment happened in government. In other institutions like government universities or polytechnic, the regulation is also implemented but limited to light punishment. In State of Jakarta Polytechnic-Indonesia for the example, most of cases are in light punishment.

The first problem is that civil servant supervisors in government institutions usually feel confused to determine the punishment level given to their staff, whether light, medium, or severe (Ariani, 2015), so the discovery of factors that influence supervisors to provide the punishment with level to civil servants' staff is essential. For this reason, this study will try to discover the factors that influence the supervisor to give the punishment level to civil servant staff- the data being used is a questionnaire to several civil servants in public academic institutions. There is too much ambiguity in the regulations (PP53 cannot categorize the punishment categories). Therefore, computational tools need to classify transgressions into punishment categories (light, medium, or severe), so this research intends to build the model for that reason by using the partial least square-structural equation modeling (PLS-SEM) approach. This research aims to propose PLS-SEM technique used for classifying civil servant discipline.

\section{METHOD}

\section{Conceptual Framework}

We have 14 hypotheses that will be observed whether this hypothesis positively affected punishment or not. They are simply whether or not coefficients are significant in a regression model. This hypothesis is derived from various empirical publications, mainly from PP53. The partial least square-structural equation modeling (PLS-SEM) will be performed to accept and reject the hypothesis.

Data is collected from the representative of civil servant supervisors in associate state polytechnic in Indonesia. The requirement demographic of the staffs are: (1) hold managerial position and has civil servant staff that directly supervised by them, (2) employed by state polytechnic in Indonesia, (3) has more than one cause for each type of punishment among light, medium and severe. The value of each hypothesis result below than benchmark should be removed from models (Sarstedt et al., 2017; Shmueli et al., 2019). The new architecture is the final model representing the punishment model for civil servants. Figure 1 explains the 14 hypotheses in this study. 


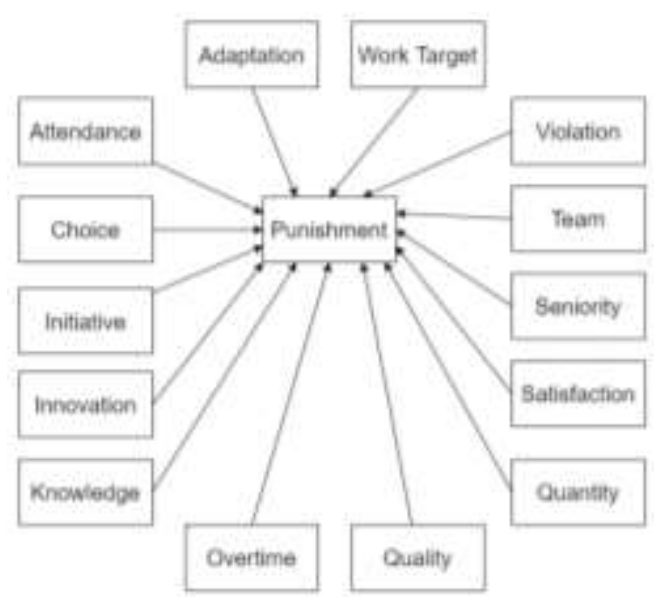

Figure 1. Research model.

Based on Figure 1, we calculate the PLS-algorithm were as follows: (1) adaptation factor has a positive influence on punishment (Adf $\rightarrow$ PF), it's derived from (Presiden Republik Indonesia, 2010); (2) less attendance has a positive influence on punishment ( $\mathrm{AF} \rightarrow \mathrm{PF}$ ), it's derived from (Epstein \& Sheldon, 2002), (Kenicer, 2008) and (Presiden Republik Indonesia, 2010); (3) choice factor has a positive influence on punishment (CF $\rightarrow$ PF), it's derived from (Presiden Republik Indonesia, 2010); (4) less initiative has a positive influence on punishment ( $\mathrm{InF} \rightarrow \mathrm{PF}$ ), it's derived from (Epstein \& Sheldon, 2002) and (Presiden Republik Indonesia, 2010); (5) less innovation has a positive influence to punishment (IF $\rightarrow$ PF), it's derived from (Epstein \& Sheldon, 2002), (Kenicer, 2008) and (Presiden Republik Indonesia, 2010); (6) less knowledge has a positive influence to punishment ( $\mathrm{KF} \rightarrow \mathrm{PF}$ ), is derived from (Epstein \& Sheldon, 2002), (Kenicer, 2008) and (Presiden Republik Indonesia, 2010); (7) working quality has a positive influence to punishment ( $\mathrm{QF} \rightarrow \mathrm{PF}$ ), is derived from (Epstein \& Sheldon, 2002), (Kenicer, 2008) and (Presiden Republik Indonesia, 2010); (8) working quantity has a positive influence to punishment (Qun $\rightarrow$ PF), is derived from (Epstein \& Sheldon, 2002), and (Presiden Republik Indonesia, 2010); (9) less satisfaction has a positive influence to punishment (SaF $\rightarrow$ PF), it's derived from (Presiden Republik Indonesia, 2010); (10) seniority has a positive influence to punishment (SF $\rightarrow$ PF), it's derived from (Kenicer, 2008) and (Presiden Republik Indonesia, 2010); (11) poor team works has a positive influence to punishment ( $T F \rightarrow P F$ ), it's derived from (Epstein \& Sheldon, 2002), (Kenicer, 2008) and (Presiden Republik Indonesia, 2010); (12) frequent violation has a positive influence to punishment (OF $\rightarrow$ PF), it's derived from (Fehr \& Fischbacher, 2004) and (Presiden Republik Indonesia, 2010); (13) less working target has a positive influence to punishment $(\mathrm{WTF} \rightarrow$ PF), it's derived from (Telep, 2009) and (Presiden Republik Indonesia, 2010); (14) less working overtime has a positive influence to punishment (Ov $\rightarrow$ PF), is derived from (Epstein \& Sheldon, 2002), (Kenicer, 2008) and (Presiden Republik Indonesia, 2010); This 14 assumptions declare as hypotheses, that we modeling these hypotheses by the following Figure 2. There is no pairwise covariance between any of the 14 factors. Each of the fourteen features and the dependent variables is explained in detail in Table 1, which is about what they mean, are measured, what kind of variable, and their domain. Because all of these hypotheses do not know what constitutes light, medium, or severe punishment or whether this changes based on the context. 
Soelaiman et al.: Modeling the civil servant discipline in Indonesia: partial least square-structural equation modeling approach

Table 1. Variable definition.

\begin{tabular}{|c|c|c|c|c|}
\hline Indicator & Notation & $\begin{array}{c}\text { Variable } \\
\text { Type }\end{array}$ & $\begin{array}{l}\text { Questionnaire } \\
\text { Measurement }\end{array}$ & Domain \\
\hline Attendance factor & $\mathrm{AF}$ & $\begin{array}{c}\text { Latent } \\
\text { Variable }\end{array}$ & With intervals $1-5$ & \multirow{4}{*}{$\begin{array}{l}\text { Mundane } \\
\text { task }\end{array}$} \\
\hline Come to work on time & AF1 & $\begin{array}{l}\text { Manifest } \\
\text { Variable }\end{array}$ & With intervals $1-5$ & \\
\hline Rarely absent from work & $\mathrm{AF} 2$ & $\begin{array}{l}\text { Manifest } \\
\text { Variable }\end{array}$ & With intervals $1-5$ & \\
\hline Always come when needed & AF3 & $\begin{array}{l}\text { Manifest } \\
\text { Variable }\end{array}$ & With intervals $1-5$ & \\
\hline Violation factor & OF & $\begin{array}{c}\text { Latent } \\
\text { Variable }\end{array}$ & With intervals $1-5$ & \multirow{4}{*}{$\begin{array}{l}\text { Mundane } \\
\text { task }\end{array}$} \\
\hline Deliberately made a mistake & OF1 & $\begin{array}{c}\text { Manifest } \\
\text { Variable } \\
\end{array}$ & With intervals $1-5$ & \\
\hline Being rude to co-workers & OF2 & $\begin{array}{l}\text { Manifest } \\
\text { Variable }\end{array}$ & With intervals $1-5$ & \\
\hline Not in line with co-workers & OF3 & $\begin{array}{l}\text { Manifest } \\
\text { Variable }\end{array}$ & With intervals $1-5$ & \\
\hline Overtime factor & $\mathrm{Ov}$ & $\begin{array}{c}\text { Latent } \\
\text { Variable }\end{array}$ & With intervals $1-5$ & \multirow{4}{*}{$\begin{array}{l}\text { Mundane } \\
\text { task }\end{array}$} \\
\hline Needs more time to complete the work & Ov1 & $\begin{array}{l}\text { Manifest } \\
\text { Variable }\end{array}$ & With intervals $1-5$ & \\
\hline Often work outside the office hours & Ov2 & $\begin{array}{l}\text { Manifest } \\
\text { Variable }\end{array}$ & With intervals $1-5$ & \\
\hline Like to do work outside the office & Ov3 & $\begin{array}{l}\text { Manifest } \\
\text { Variable }\end{array}$ & With intervals $1-5$ & \\
\hline Initiative factor & $\operatorname{InF}$ & $\begin{array}{c}\text { Latent } \\
\text { Variable }\end{array}$ & With intervals $1-5$ & \multirow{4}{*}{$\begin{array}{l}\text { Mundane } \\
\text { task }\end{array}$} \\
\hline $\begin{array}{l}\text { Took the initiative when a problem } \\
\text { occurred }\end{array}$ & InF1 & $\begin{array}{l}\text { Manifest } \\
\text { Variable }\end{array}$ & With intervals $1-5$ & \\
\hline Always ask for help when needed & InF2 & $\begin{array}{l}\text { Manifest } \\
\text { Variable }\end{array}$ & With intervals $1-5$ & \\
\hline $\begin{array}{l}\text { Have creative ideas in dealing with } \\
\text { problems }\end{array}$ & InF3 & $\begin{array}{c}\text { Manifest } \\
\text { Variable }\end{array}$ & With intervals $1-5$ & \\
\hline Team factor & $\mathrm{TF}$ & $\begin{array}{c}\text { Latent } \\
\text { Variable }\end{array}$ & With intervals $1-5$ & \multirow{4}{*}{$\begin{array}{c}\text { Mundane } \\
\text { task }\end{array}$} \\
\hline Can work well together & TF1 & $\begin{array}{l}\text { Manifest } \\
\text { Variable }\end{array}$ & With intervals $1-5$ & \\
\hline Understand what the supervisor said & TF2 & $\begin{array}{l}\text { Manifest } \\
\text { Variable }\end{array}$ & With intervals $1-5$ & \\
\hline $\begin{array}{l}\text { Understand what explained by co- } \\
\text { workers or team members }\end{array}$ & TF3 & $\begin{array}{l}\text { Manifest } \\
\text { Variable }\end{array}$ & With intervals $1-5$ & \\
\hline Seniority factor & SF & $\begin{array}{c}\text { Latent } \\
\text { Variable }\end{array}$ & With intervals $1-5$ & \multirow{4}{*}{$\begin{array}{l}\text { Expert } \\
\text { task }\end{array}$} \\
\hline Staff followed their senior direction & SF1 & $\begin{array}{l}\text { Manifest } \\
\text { Variable }\end{array}$ & With intervals $1-5$ & \\
\hline Take more discussion with senior & SF2 & $\begin{array}{l}\text { Manifest } \\
\text { Variable }\end{array}$ & With intervals $1-5$ & \\
\hline Always prioritizes seniority & SF3 & $\begin{array}{l}\text { Manifest } \\
\text { Variable }\end{array}$ & With intervals $1-5$ & \\
\hline
\end{tabular}




\begin{tabular}{|c|c|c|c|c|}
\hline Knowledge factor & KF & $\begin{array}{c}\text { Latent } \\
\text { Variable }\end{array}$ & With intervals $1-5$ & \multirow{4}{*}{$\begin{array}{l}\text { Mundane } \\
\text { task }\end{array}$} \\
\hline $\begin{array}{l}\text { Have knowledge and ability to solve a } \\
\text { problem }\end{array}$ & KF1 & $\begin{array}{l}\text { Manifest } \\
\text { Variable }\end{array}$ & With intervals $1-5$ & \\
\hline $\begin{array}{l}\text { Always looking for knowledge to } \\
\text { improve the quality of work }\end{array}$ & KF2 & $\begin{array}{l}\text { Manifest } \\
\text { Variable }\end{array}$ & With intervals $1-5$ & \\
\hline $\begin{array}{c}\text { The knowledge and skills are under } \\
\text { the job }\end{array}$ & KF3 & $\begin{array}{l}\text { Manifest } \\
\text { Variable }\end{array}$ & With intervals $1-5$ & \\
\hline Work target factor & WTF & $\begin{array}{c}\text { Latent } \\
\text { Variable }\end{array}$ & With intervals $1-5$ & \multirow{5}{*}{$\begin{array}{l}\text { Expert } \\
\text { task }\end{array}$} \\
\hline Completed work on time & WTF1 & $\begin{array}{l}\text { Manifest } \\
\text { Variable } \\
\end{array}$ & With intervals $1-5$ & \\
\hline Works with a reasonable time & WTF2 & $\begin{array}{l}\text { Manifest } \\
\text { Variable }\end{array}$ & With intervals $1-5$ & \\
\hline Collect work on time & WTF3 & $\begin{array}{l}\text { Manifest } \\
\text { Variable }\end{array}$ & With intervals $1-5$ & \\
\hline Works when near deadlines & WTF4 & $\begin{array}{l}\text { Manifest } \\
\text { Variable }\end{array}$ & With intervals $1-5$ & \\
\hline Choice factor & $\mathrm{CF}$ & $\begin{array}{c}\text { Latent } \\
\text { Variable }\end{array}$ & With intervals $1-5$ & \multirow{4}{*}{$\begin{array}{l}\text { Mundane } \\
\text { task }\end{array}$} \\
\hline $\begin{array}{c}\text { Can provide a personal assessment on } \\
\text { work }\end{array}$ & CF1 & $\begin{array}{l}\text { Manifest } \\
\text { Variable }\end{array}$ & With intervals $1-5$ & \\
\hline $\begin{array}{c}\text { Can make many self-decisions on } \\
\text { work }\end{array}$ & CF2 & $\begin{array}{l}\text { Manifest } \\
\text { Variable }\end{array}$ & With intervals $1-5$ & \\
\hline Can make a right decision & CF3 & $\begin{array}{l}\text { Manifest } \\
\text { Variable } \\
\end{array}$ & With intervals $1-5$ & \\
\hline Adaptation factor & Adf & $\begin{array}{c}\text { Latent } \\
\text { Variable }\end{array}$ & With intervals $1-5$ & \multirow{5}{*}{$\begin{array}{l}\text { Mundane } \\
\text { task }\end{array}$} \\
\hline $\begin{array}{c}\text { Overcome bad situations and obstacles } \\
\text { well }\end{array}$ & Adf1 & $\begin{array}{l}\text { Manifest } \\
\text { Variable }\end{array}$ & With intervals $1-5$ & \\
\hline $\begin{array}{l}\text { It can quickly be returned to normal } \\
\text { after a bad situation }\end{array}$ & Adf2 & $\begin{array}{l}\text { Manifest } \\
\text { Variable }\end{array}$ & With intervals $1-5$ & \\
\hline $\begin{array}{c}\text { Can quickly adapt to change in any } \\
\text { work environment }\end{array}$ & Adf3 & $\begin{array}{l}\text { Manifest } \\
\text { Variable }\end{array}$ & With intervals $1-5$ & \\
\hline $\begin{array}{l}\text { When a situation cannot be predicted, } \\
\text { it can handle }\end{array}$ & Adf4 & $\begin{array}{l}\text { Manifest } \\
\text { Variable } \\
\end{array}$ & With intervals $1-5$ & \\
\hline Quantity factor & Qun & $\begin{array}{c}\text { Latent } \\
\text { Variable }\end{array}$ & With intervals $1-5$ & \multirow{4}{*}{$\begin{array}{c}\text { Formal } \\
\text { task }\end{array}$} \\
\hline Work quantity always fulfilled & Qun1 & $\begin{array}{l}\text { Manifest } \\
\text { Variable }\end{array}$ & With intervals $1-5$ & \\
\hline $\begin{array}{l}\text { Can arrange all work well, so the work } \\
\text { is finished on time }\end{array}$ & Qun2 & $\begin{array}{l}\text { Manifest } \\
\text { Variable }\end{array}$ & With intervals $1-5$ & \\
\hline $\begin{array}{l}\text { In the last three months, the number of } \\
\text { works was increased }\end{array}$ & Qun3 & $\begin{array}{c}\text { Manifest } \\
\text { Variable }\end{array}$ & With intervals $1-5$ & \\
\hline Innovation factor & IF & $\begin{array}{c}\text { Latent } \\
\text { Variable }\end{array}$ & With intervals $1-5$ & \multirow{2}{*}{$\begin{array}{c}\text { Mundane } \\
\text { task }\end{array}$} \\
\hline Have a quite innovative in working & IF1 & $\begin{array}{c}\text { Manifest } \\
\text { Variable }\end{array}$ & With intervals $1-5$ & \\
\hline
\end{tabular}


Soelaiman et al.: Modeling the civil servant discipline in Indonesia: partial least square-structural equation modeling approach

\begin{tabular}{|c|c|c|c|c|}
\hline Very creative while working & IF2 & $\begin{array}{l}\text { Manifest } \\
\text { Variable }\end{array}$ & With intervals $1-5$ & \\
\hline Shows the ability to innovate in work & IF3 & $\begin{array}{l}\text { Manifest } \\
\text { Variable }\end{array}$ & With intervals $1-5$ & \\
\hline Convinced colleagues to innovate & IF4 & $\begin{array}{l}\text { Manifest } \\
\text { Variable }\end{array}$ & With intervals $1-5$ & \\
\hline $\begin{array}{l}\text { Can give the advise improving the } \\
\text { quality of work }\end{array}$ & IF5 & $\begin{array}{l}\text { Manifest } \\
\text { Variable }\end{array}$ & With intervals $1-5$ & \\
\hline $\begin{array}{l}\text { Always looking for ways to work } \\
\text { better than before }\end{array}$ & IF6 & $\begin{array}{l}\text { Manifest } \\
\text { Variable }\end{array}$ & With intervals $1-5$ & \\
\hline Quality factor & QF & $\begin{array}{l}\text { Latent } \\
\text { Variable }\end{array}$ & With intervals $1-5$ & \multirow{6}{*}{$\begin{array}{l}\text { Expert } \\
\text { task }\end{array}$} \\
\hline Carefully while working & QF1 & $\begin{array}{l}\text { Manifest } \\
\text { Variable }\end{array}$ & With intervals $1-5$ & \\
\hline Work-based on criteria and SOP & QF2 & $\begin{array}{l}\text { Manifest } \\
\text { Variable }\end{array}$ & With intervals $1-5$ & \\
\hline $\begin{array}{l}\text { Work that has been completed under } \\
\text { applicable criteria and SOP }\end{array}$ & QF3 & $\begin{array}{l}\text { Manifest } \\
\text { Variable }\end{array}$ & With intervals $1-5$ & \\
\hline $\begin{array}{c}\text { Work that has been completed meets } \\
\text { expectations }\end{array}$ & QF4 & $\begin{array}{l}\text { Manifest } \\
\text { Variable }\end{array}$ & With intervals $1-5$ & \\
\hline $\begin{array}{l}\text { The quality of work that finished was } \\
\text { done very well }\end{array}$ & QF5 & $\begin{array}{l}\text { Manifest } \\
\text { Variable }\end{array}$ & With intervals $1-5$ & \\
\hline Satisfaction factor & $\mathrm{SaF}$ & $\begin{array}{c}\text { Latent } \\
\text { Variable }\end{array}$ & With intervals $1-5$ & \multirow{7}{*}{$\begin{array}{l}\text { Mundane } \\
\text { task }\end{array}$} \\
\hline Always satisfied with work conditions & SaF1 & $\begin{array}{l}\text { Manifest } \\
\text { Variable }\end{array}$ & With intervals $1-5$ & \\
\hline $\begin{array}{l}\text { Always satisfied with the praise that } \\
\text { given by supervisor when they do } \\
\text { work well }\end{array}$ & SaF2 & $\begin{array}{l}\text { Manifest } \\
\text { Variable }\end{array}$ & With intervals $1-5$ & \\
\hline $\begin{array}{c}\text { Always satisfied with the freedom to } \\
\text { assess their work }\end{array}$ & SaF3 & $\begin{array}{l}\text { Manifest } \\
\text { Variable }\end{array}$ & With intervals $1-5$ & \\
\hline $\begin{array}{l}\text { Always satisfied with the freedom } \\
\text { given to do work with the own method }\end{array}$ & SaF4 & $\begin{array}{l}\text { Manifest } \\
\text { Variable }\end{array}$ & With intervals $1-5$ & \\
\hline $\begin{array}{l}\text { Always satisfied with the income and } \\
\text { the amount of work given }\end{array}$ & SaF5 & $\begin{array}{l}\text { Manifest } \\
\text { Variable }\end{array}$ & With intervals $1-5$ & \\
\hline Like the current job & SaF6 & $\begin{array}{l}\text { Manifest } \\
\text { Variable }\end{array}$ & With intervals $1-5$ & \\
\hline Punishment factor & $\mathrm{PF}$ & $\begin{array}{c}\text { Latent } \\
\text { Variable }\end{array}$ & With intervals $1-5$ & \multirow{5}{*}{$\begin{array}{l}\text { Expert } \\
\text { task }\end{array}$} \\
\hline $\begin{array}{c}\text { Constantly reprimanded when making } \\
\text { a mistake }\end{array}$ & PF1 & $\begin{array}{l}\text { Manifest } \\
\text { Variable }\end{array}$ & With intervals $1-5$ & \\
\hline Can accept the punishment & PF2 & $\begin{array}{l}\text { Manifest } \\
\text { Variable }\end{array}$ & With intervals $1-5$ & \\
\hline $\begin{array}{l}\text { Have commemorated if not good at } \\
\text { work }\end{array}$ & PF3 & $\begin{array}{l}\text { Manifest } \\
\text { Variable }\end{array}$ & With intervals $1-5$ & \\
\hline $\begin{array}{l}\text { Not approve or receive jobs if the } \\
\text { work is not as expected }\end{array}$ & PF4 & $\begin{array}{l}\text { Manifest } \\
\text { Variable }\end{array}$ & With intervals $1-5$ & \\
\hline
\end{tabular}




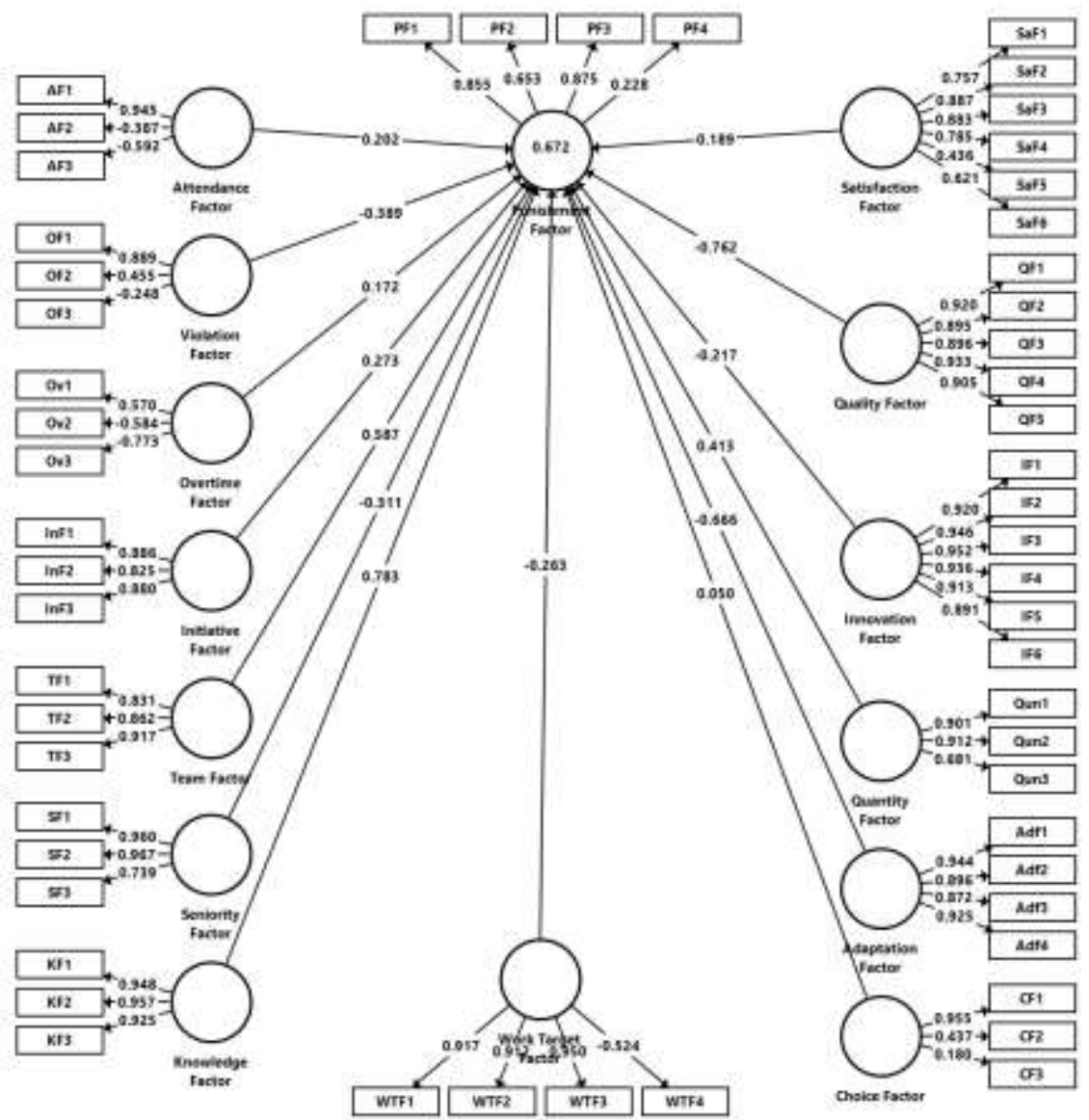

Figure 2. Initial PLS-Path model.

Based on Figure 2, we calculate the PLS-algorithm to give the loading factor (LF) results for each item code. For the value of LF, if the LF's value is below 0.7, it has been deleted. For this reason, based on the confirmatory research type in this study (Sarstedt et al., 2017, 2020). Hypothesis 14 (Ov $\rightarrow \mathrm{PF}$ ) has been deleted caused by the value of LF $<0.7$ for all item codes, but some item codes we not deleted for the value of 0.6, so the valid model of PLS-path can be seen in Figure 3. 
Soelaiman et al.: Modeling the civil servant discipline in Indonesia: partial least square-structural equation modeling approach

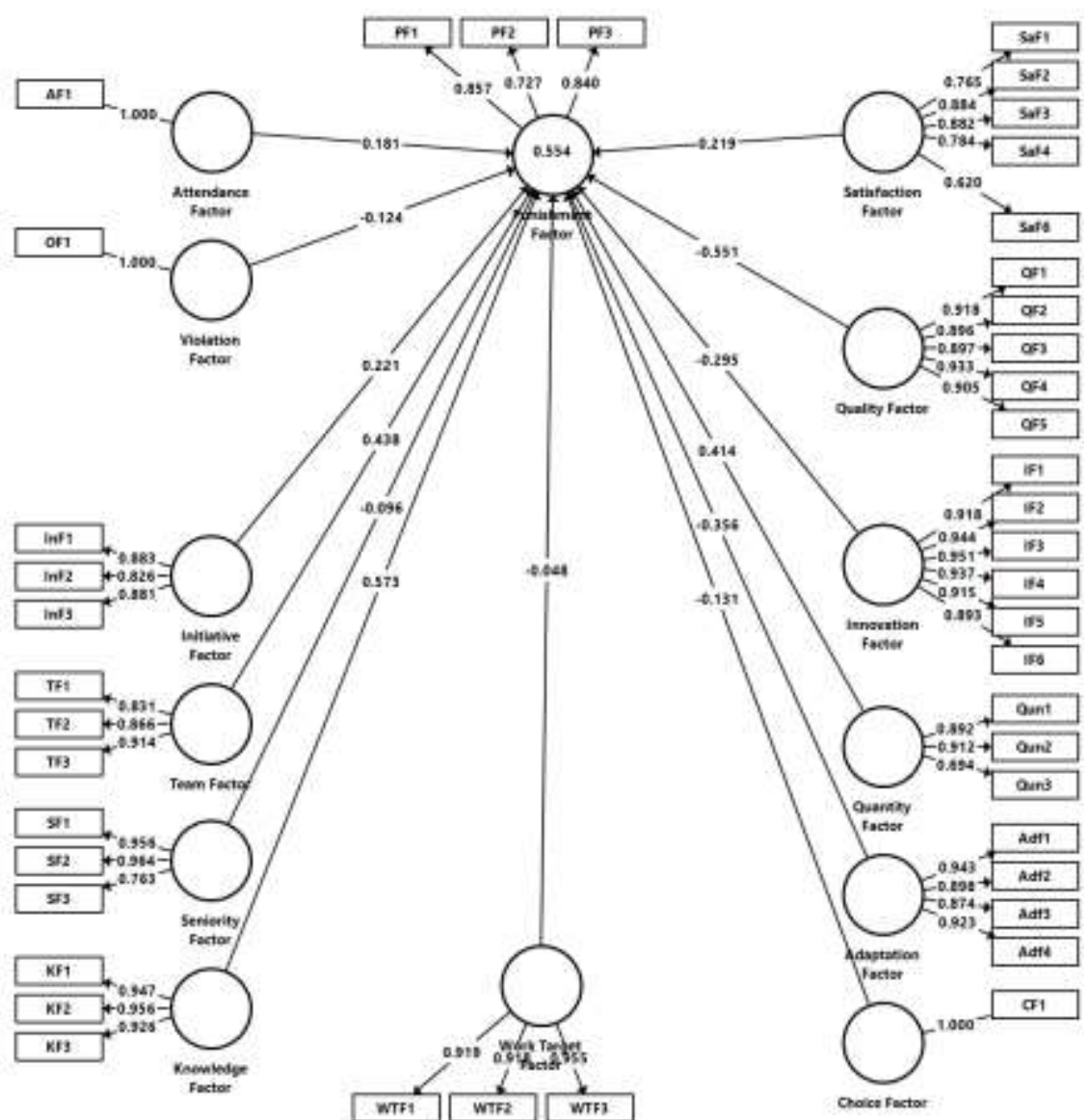

Figure 3. Modified PLS-Path model.

Based on Figure 3, we only have 13 hypotheses that would like to know the p-value for each hypothesis later using bootstrapping. The bootstrapping procedure can be used if the data situation does not meet the normality assumption or analyze non-normal data (Sharma \& Kim, 2013). The bootstrapping method can obtain the estimates of path analysis (Awang et al., 2015).

\section{Sample}

We used respondents to fulfill the questionnaire data; this research involved a small group of 42 civil servants from some state polytechnic in Indonesia (purposive random sampling). All civil servants registered in the Indonesian government participated in the survey. Before the data analysis, the researchers "cleaned and accounted" the data from errors and uncompleted ones (Creswell, 2012) for data filtering. The data cleaning process included checking the students' responses on each item in the research instrument to ensure that the respondents completed all statements; re-ranking each negative report was also conducted simultaneously. As a result, 42 civil servants were considered eligible for the following data analysis phase. Table 2 explains the total number of respondents based on gender.

Table 2. Respondents' profile demography is based on gender.

\begin{tabular}{lcc}
\hline Gender & Number (n) & Percentage (\%) \\
\hline Male & 21 & 50 \\
\hline Female & 21 & 50 \\
\hline Total & $\mathbf{4 2}$ & $\mathbf{1 0 0}$ \\
\hline
\end{tabular}




\section{Data Analysis}

We have 14 hypotheses that will be observed whether this hypothesis positively affected punishment or not. This research will determine the model of influence factors of discipline in civil servants in Indonesia. The next phase will analyze the discriminant validity: heterotrait-monotrait ratio (HTMT) and Fornell and Larcker Criterion. We focus on developing influence factors of the punishment model for civil servants derived from Indonesian Government Regulation No. 532010 (PP53). Then, the construct would build based on empirical research from various scientific papers and books. Then the construct will be spread out into civil servant employees and supervisors located in associate of state polytechnic in Indonesia. After having appropriate data, the data is then analyzed using Structural Equation Modeling (SEM) combined with Partial Least Square (PLS) to obtain the final model of influence factors of punishment model to a civil servant (analysis of accepted factors). The model is then used as a parameter that can determine civil servant punishment type.

Data processing procedures for this research are as the following. We used an online questionnaire to assess civil servants. The online questionnaire was initially developed in the Indonesian language. To obtain a valid and reliable measurement used in the context of factors that influence the punishment for civil servants, the questionnaire was first adapted into the English version (USstandard). The translation process of this questionnaire was conducted through standard translation methodology, including translation, verification, and modification (Maison et al., 2019). All of the items were translated into English (US). The result was then validated qualitatively by each supervisor of the employees. The feedback provided by the validators was adopted as the basis for improving the translation versions of the questionnaires.

For this study, we conducted one stage of data analysis, confirmatory factor analysis (CFA) (Sarstedt et al., 2017). Hence, we set the data into a dataset. The dataset was used for confirmatory factor analysis (CFA) test using PLS-based SEM (PLS-SEM). The CFA was conducted on the questionnaire to measure civil servant punishment in Indonesia. The questionnaire consists of 56 statement items (manifest variable) categorized into 15 (latent variable). Each group contains a minimum of 3 statement items and a maximum of 6 statement items. Then the CFA test was performed to analyze the convergent validity (Maison et al., 2019) for the factors influencing civil servant punishment in Indonesia. The CFA test was also conducted to examine the structural model of the correlation (Maison et al., 2019) between the 15 latent variables of this study; there are punishment factor, attendance factor, violation factor, overtime factor, initiative factor, team factor, seniority factor, knowledge factor, satisfaction factor, quality factor, innovation factor, quantity factor, adaptation factor, choice factor, and work target factor. We also conducted CFA instrument validation (discriminant validity), such as outer loading (OL), composite reliability (CR), average variance extracted (AVE) for each instrument were examined (Nawanir et al., 2020). Finally, we performed structural equation modeling (SEM), which is based on variance (PLS-SEM), to analyze the fit of the research model (Maison et al., 2019) in Figure 1. The PLS approach is asymptotic distribution-free (ADF) for the interpreted data that cannot possess a specific distribution pattern. It can be ratio, interval, ordinal, category, and nominal (Maison et al., 2019). Lastly, data science techniques such as Pearson Correlation and Exploratory Data Analysis improve PLS-SEM processes. This gives us an initial indication of a positive linear relationship between these two variables. 
Soelaiman et al.: Modeling the civil servant discipline in Indonesia: partial least square-structural equation modeling approach

\section{RESULT AND DISCUSSION}

We run the descriptive statistics and normality assessment for the first analysis. All item code (constructs, manifest variables) has been accepted for the normality assessment. This is because Excess Kurtosis and Skewness values are not above 2.000 (Arifin, 2017), so all the data can be analyzed for the next phase, convergent validity and reliability assessment, also discriminant validity.

Table 3. Demographic profile of respondents.

\begin{tabular}{lll}
\hline \multicolumn{1}{c}{ Demographic Profile } & Count (n) & $\%$ \\
\hline \multicolumn{1}{c}{ Institution } & \\
\hline State Polytechnic of Bali & 1 & $2.38 \%$ \\
\hline State Polytechnic of Bandung & 2 & $4.76 \%$ \\
\hline State Polytechnic of Jakarta & 19 & $45.24 \%$ \\
\hline State Polytechnic of Jember & 6 & $14.29 \%$ \\
\hline State Polytechnic of Lampung & 6 & $14.29 \%$ \\
\hline $\begin{array}{l}\text { State Polytechnic of } \\
\text { Lhokseumawe }\end{array}$ & 2 & $4.76 \%$ \\
\hline State Polytechnic of Padang & 1 & $2.38 \%$ \\
\hline State Polytechnic of Semarang & 2 & $4.76 \%$ \\
\hline State Polytechnic of Sriwijaya & 2 & $4.76 \%$ \\
\hline University of Indonesia & 1 & $2.38 \%$ \\
\hline \multicolumn{3}{c}{ Work Experience (years) } \\
\hline$<1$ & 2 & $4.76 \%$ \\
\hline $1-5$ & 7 & $16.67 \%$ \\
\hline $6-10$ & 2 & $4.76 \%$ \\
\hline $11-15$ & 5 & $11.90 \%$ \\
\hline$>15$ & 26 & $61.90 \%$ \\
\hline \multicolumn{2}{c}{ Gender } \\
\hline Female & 21 & \\
\hline Male & 21 & $50.00 \%$ \\
\hline Grand Total & 42 \\
\hline
\end{tabular}

Based on Table 3, this study dominance of the respondent by the lecturer of State Polytechnic of Jakarta $(n=19)$, with work experience of more than 15 years $(n=26)$ and with both sex female and male $(n=21)$. The output of the concurrent validity assessment is shown in Table 4 .

Table 4. Convergent validity and reliability.

\begin{tabular}{ccccc}
\hline Construct & Item Code & OL & CR & AVE \\
\hline \multirow{3}{*}{ Adf } & Adf1 & 0.943 & & \\
\cline { 2 - 3 } & Adf2 & 0.898 & & \\
\cline { 2 - 3 } & Adf3 & 0.874 & 0.950 & 0.828 \\
\cline { 2 - 3 } & Adf4 & 0.923 & & \\
\hline AF & AF1 & 1.000 & 1.000 & 1.000 \\
\hline CF & CF1 & 1.000 & 1.000 & 1.000 \\
\hline & IF1 & 0.918 & & \\
\cline { 2 - 3 } & IF2 & 0.944 & & \\
IF & IF3 & 0.951 & & \\
\cline { 2 - 3 } & IF4 & 0.937 & 0.973 & 0.858 \\
& IF5 & 0.915 & & \\
\cline { 2 - 3 } & IF6 & 0.893 & & \\
\hline Inf & InF1 & 0.883 & 0.898 & 0.746 \\
\hline
\end{tabular}




\begin{tabular}{|c|c|c|c|c|}
\hline & $\mathrm{InF} 2$ & 0.826 & & \\
\hline & InF3 & 0.881 & & \\
\hline \multirow{3}{*}{$\mathrm{KF}$} & KF1 & 0.947 & \multirow{3}{*}{0.960} & \multirow{3}{*}{0.889} \\
\hline & KF2 & 0.956 & & \\
\hline & KF3 & 0.926 & & \\
\hline $\mathrm{OF}$ & OF1 & 1.000 & 1.000 & 1.000 \\
\hline \multirow{5}{*}{$\mathrm{QF}$} & QF1 & 0.918 & \multirow{5}{*}{0.960} & \multirow{5}{*}{0.828} \\
\hline & QF2 & 0.896 & & \\
\hline & QF3 & 0.897 & & \\
\hline & QF4 & 0.933 & & \\
\hline & QF5 & 0.905 & & \\
\hline \multirow{3}{*}{ Qun } & Qun1 & 0.892 & \multirow{3}{*}{0.875} & \multirow{3}{*}{0.703} \\
\hline & Qun2 & 0.912 & & \\
\hline & Qun3 & 0.694 & & \\
\hline \multirow{3}{*}{$\mathrm{SF}$} & SF1 & 0.956 & \multirow{3}{*}{0.926} & \multirow{3}{*}{0.809} \\
\hline & SF2 & 0.964 & & \\
\hline & SF3 & 0.763 & & \\
\hline \multirow{5}{*}{$\mathrm{SaF}$} & $\mathrm{SaF} 1$ & 0.765 & \multirow{5}{*}{0.893} & \multirow{5}{*}{0.629} \\
\hline & $\mathrm{SaF} 2$ & 0.884 & & \\
\hline & SaF3 & 0.882 & & \\
\hline & $\mathrm{SaF} 4$ & 0.784 & & \\
\hline & SaF6 & 0.620 & & \\
\hline \multirow{3}{*}{$\mathrm{TF}$} & TF1 & 0.831 & \multirow{3}{*}{0.904} & \multirow{3}{*}{0.759} \\
\hline & TF2 & 0.866 & & \\
\hline & TF3 & 0.914 & & \\
\hline \multirow{3}{*}{ WTF } & WTF1 & 0.919 & \multirow{3}{*}{0.951} & \multirow{3}{*}{0.867} \\
\hline & WTF2 & 0.918 & & \\
\hline & WTF3 & 0.955 & & \\
\hline
\end{tabular}

Based on Table 4, the low outer loading (OL) value, if below 0.4 were deleted (Leguina, 2015). Then, composite reliability (CR) and average variance extracted (AVE) values show adequate convergent validity for all constructs, which have exceeded 0.5 and 0.7 (Franke \& Sarstedt, 2019). The next phase will analyze the discriminant validity: heterotrait-monotrait ratio (HTMT) (Table 5) and Fornell and Larcker Criterion (Table 6). These discriminant validity tests can assume that the square root of AVE values of all constructs is higher than the correlation values with any other constructs and all constructs distinct from each other (Nawanir et al., 2020).

Table 5. Discriminant validity: HTMT assessment.

\begin{tabular}{|c|c|c|c|c|c|c|c|c|c|c|c|c|c|c|}
\hline & Adf & $\mathbf{A F}$ & $\mathbf{C F}$ & InF & IF & KF & PF & $\mathbf{Q F}$ & $\begin{array}{l}\text { Qu } \\
\mathbf{n}\end{array}$ & $\mathrm{SaF}$ & SF & $\mathbf{T F}$ & OF & $\begin{array}{l}\text { WT } \\
\text { F } \\
\end{array}$ \\
\hline Adf & & & & & & & & & & & & & & \\
\hline $\mathbf{A F}$ & $\begin{array}{l}0.39 \\
6\end{array}$ & & & & & & & & & & & & & \\
\hline $\mathbf{C F}$ & $\begin{array}{l}0.35 \\
4\end{array}$ & $\begin{array}{l}0.47 \\
9\end{array}$ & & & & & & & & & & & & \\
\hline InF & $\begin{array}{l}0.74 \\
1\end{array}$ & $\begin{array}{l}0.50 \\
3\end{array}$ & $\begin{array}{l}0.50 \\
6\end{array}$ & & & & & & & & & & & \\
\hline IF & $\begin{array}{l}0.85 \\
7\end{array}$ & $\begin{array}{l}0.48 \\
2\end{array}$ & $\begin{array}{l}0.32 \\
3\end{array}$ & $\begin{array}{l}0.80 \\
5\end{array}$ & & & & & & & & & & \\
\hline
\end{tabular}


Soelaiman et al.: Modeling the civil servant discipline in Indonesia: partial least square-structural equation modeling approach

\begin{tabular}{|c|c|c|c|c|c|c|c|c|c|c|c|c|c|}
\hline \multirow{2}{*}{ KF } & 0.90 & 0.53 & 0.48 & 0.89 & 0.87 & & & & & & & & \\
\hline & 5 & 4 & 8 & 9 & 6 & & & & & & & & \\
\hline \multirow{2}{*}{$\mathbf{P F}$} & 0.47 & 0.45 & 0.31 & 0.64 & 0.41 & 0.69 & & & & & & & \\
\hline & 9 & 9 & 9 & 8 & 8 & 2 & & & & & & & \\
\hline \multirow{2}{*}{$\mathbf{Q F}$} & 0.82 & 0.53 & 0.48 & 0.73 & 0.75 & 0.91 & 0.62 & & & & & & \\
\hline & 2 & 0 & 9 & 6 & 1 & 9 & 6 & & & & & & \\
\hline \multirow{2}{*}{ Qun } & 0.85 & 0.53 & 0.36 & 0.82 & 0.76 & 0.95 & 0.78 & 1.02 & & & & & \\
\hline & 6 & 8 & 6 & 6 & 3 & 1 & 6 & 9 & & & & & \\
\hline \multirow{2}{*}{ SaF } & 0.32 & 0.36 & 0.58 & 0.38 & 0.31 & 0.52 & 0.61 & 0.46 & 0.50 & & & & \\
\hline & 4 & 1 & 6 & 6 & 4 & 1 & 5 & 5 & 0 & & & & \\
\hline \multirow{2}{*}{ SF } & 0.43 & 0.25 & 0.08 & 0.25 & 0.33 & 0.47 & 0.27 & 0.47 & 0.59 & 0.15 & & & \\
\hline & 4 & 4 & 8 & 6 & 1 & 6 & 3 & 9 & 4 & 6 & & & \\
\hline \multirow{2}{*}{ TF } & 0.84 & 0.33 & 0.45 & 0.75 & 0.68 & 0.85 & 0.67 & 0.93 & 0.88 & 0.49 & 0.25 & & \\
\hline & 8 & 8 & 6 & 9 & 6 & 4 & 3 & 6 & 6 & 8 & 8 & & \\
\hline \multirow{2}{*}{ OF } & 0.53 & 0.33 & 0.18 & 0.24 & 0.42 & 0.40 & 0.24 & 0.45 & 0.38 & 0.24 & 0.15 & 0.35 & \\
\hline & 6 & 2 & 2 & 4 & 0 & 9 & 1 & 9 & 1 & 8 & 7 & 9 & \\
\hline WT & 0.63 & 0.62 & 0.46 & 0.70 & 0.66 & 0.81 & 0.58 & 0.85 & 0.84 & 0.27 & 0.46 & 0.75 & 0.42 \\
\hline $\mathbf{F}$ & 7 & 5 & 6 & 4 & 0 & 8 & 3 & 1 & 6 & 8 & 5 & 2 & 2 \\
\hline
\end{tabular}

Table 6. Discriminant validity: Fornell and Larcker criterion.

\begin{tabular}{|c|c|c|c|c|c|c|c|c|c|c|c|c|c|c|}
\hline & Adf & AF & CF & InF & IF & KF & PF & QF & Qun & SaF & SF & TF & OF & WTF \\
\hline Adf & 0.910 & & & & & & & & & & & & & \\
\hline $\mathbf{A F}$ & 0.372 & 1.000 & & & & & & & & & & & & \\
\hline $\mathbf{C F}$ & 0.357 & 0.479 & 1.000 & & & & & & & & & & & \\
\hline InF & 0.657 & 0.437 & 0.457 & 0.864 & & & & & & & & & & \\
\hline IF & 0.819 & 0.477 & 0.320 & 0.708 & 0.926 & & & & & & & & & \\
\hline KF & 0.859 & 0.517 & 0.471 & 0.789 & 0.835 & 0.943 & & & & & & & & \\
\hline PF & 0.416 & 0.390 & 0.278 & 0.533 & 0.357 & 0.579 & 0.810 & & & & & & & \\
\hline $\mathbf{Q F}$ & 0.780 & 0.517 & 0.478 & 0.659 & 0.724 & 0.869 & 0.520 & 0.910 & & & & & & \\
\hline Qun & 0.749 & 0.472 & 0.336 & 0.685 & 0.677 & 0.825 & 0.588 & 0.896 & 0.838 & & & & & \\
\hline SaF & 0.305 & 0.349 & 0.538 & 0.319 & 0.278 & 0.472 & 0.493 & 0.415 & 0.403 & 0.793 & & & & \\
\hline SF & -0.402 & -0.200 & 0.057 & -0.233 & -0.305 & -0.434 & -0.257 & -0.441 & -0.515 & 0.080 & 0.899 & & & \\
\hline TF & 0.764 & 0.308 & 0.420 & 0.639 & 0.618 & 0.757 & 0.527 & 0.836 & 0.736 & 0.417 & -0.233 & 0.871 & & \\
\hline OF & -0.506 & -0.332 & -0.182 & -0.155 & -0.416 & -0.396 & -0.208 & -0.447 & -0.352 & -0.238 & 0.118 & -0.333 & 1.000 & \\
\hline WTF & 0.593 & 0.601 & 0.448 & 0.608 & 0.623 & 0.759 & 0.472 & 0.796 & 0.733 & 0.248 & -0.396 & 0.657 & -0.404 & 0.931 \\
\hline
\end{tabular}

Note: Diagonal values are the square root of AVE, off-diagonals are correlation coefficients.

Based on Tables 5 and 6 , the results of the discriminant validity test have shown the valid value for each item code (higher than each below values). So, the next phase is multicollinearity support analysis (Table 7).

Table 7. Multicollinearity support.

\begin{tabular}{ccc}
\hline Construct & PF & Multicollinearity \\
\hline Adf & 9.361 & Supported \\
\hline AF & 2.073 & Supported \\
\hline CF & 2.488 & Supported \\
\hline InF & 4.117 & Supported \\
\hline IF & 4.876 & Supported \\
\hline KF & 15.182 & Not Supported \\
\hline QF & 14.616 & Not Supported \\
\hline Qun & 8.418 & Supported \\
\hline SaF & 2.858 & Supported \\
\hline SF & 2.072 & Supported \\
\hline TF & 6.260 & Supported \\
\hline
\end{tabular}




\begin{tabular}{ccc}
\hline OF & 1.974 & Supported \\
\hline WTF & 4.783 & Supported \\
\hline
\end{tabular}

Note: multicollinearity supported if $<10$ (Sarstedt et al., 2017).

Based on Table 7, the results of the multicollinearity support test have shown the supported value for Adf, AF, CF, InF, IF, Qun, SaF, SF, TF, OF, WTF construct. These constructs can support multicollinearity for more than two variables. Then, the next phase analysis can be run due to the hypothesis testing with bootstrapping procedure (Table 8). 
Soelaiman et al.: Modeling the civil servant discipline in Indonesia: partial least square-structural equation modeling approach

Table 8. Summary of path-hypotheses testing.

\begin{tabular}{ccccccc}
\hline \multirow{2}{*}{ Hypotheses } & \multirow{2}{*}{ Std. Dev. } & \multirow{2}{*}{ Bias } & \multicolumn{2}{c}{ Confidence Interval } & \multirow{2}{*}{ t-value } & \multirow{2}{*}{ p-value } \\
\cline { 5 - 6 } & & $\mathbf{5 . 0 0 \%}$ & $\mathbf{9 5 . 0 0 \%}$ & & \\
\hline H1 & 0.397 & 0.053 & -0.982 & 0.335 & 0.897 & 0.185 \\
\hline H2 & 0.222 & 0.010 & -0.159 & 0.583 & 0.814 & 0.208 \\
\hline H3 & 0.216 & -0.034 & -0.404 & 0.303 & 0.604 & 0.273 \\
\hline H4 & 0.339 & 0.062 & -0.329 & 0.760 & 0.653 & 0.257 \\
\hline H5 & 0.296 & 0.029 & -0.971 & 0.038 & 0.998 & 0.159 \\
\hline H6 & 0.668 & -0.158 & -0.288 & 1.788 & 0.857 & 0.196 \\
\hline H7 & 0.575 & 0.115 & -1.542 & 0.275 & 0.958 & 0.169 \\
\hline H8 & 0.397 & -0.035 & -0.152 & 1.127 & 1.041 & 0.149 \\
\hline H9 & 0.229 & 0.058 & -0.240 & 0.518 & 0.954 & 0.170 \\
\hline H10 & 0.269 & -0.016 & -0.471 & 0.384 & 0.357 & 0.361 \\
\hline H1 & 0.371 & -0.024 & -0.152 & 1.029 & 1.182 & 0.119 \\
\hline H12 & 0.174 & 0.013 & -0.426 & 0.149 & 0.713 & 0.238 \\
\hline H13 & 0.313 & -0.021 & -0.491 & 0.501 & 0.153 & 0.439 \\
\hline
\end{tabular}

*Note: $\mathrm{p} \leq 0.05$ (one-tailed test).

The p-value of each hypothesis (H1-H13) shown not significantly different ( $p>0.05$ with onetailed test), which means that attendance factor, violation factor, initiative factor, team factor, seniority factor, knowledge factor, satisfaction factor, quality factor, innovation factor, quantity factor, adaptation factor, choice factor, and work target factor does not influence the civil servant discipline in Indonesia. Based on the loading factor (LF) criteria, the overtime factor has been removed due to a low LF value (below 0.7), so it can be explained that the overtime factor does not correlate with the influence factor of civil servant discipline in Indonesia.

All of these factors (except the overtime factor) did not show a level of significance in the correlation path. Still, there was an indication of the relationship for each element to the punishment factor. This study implies that the model of civil servant discipline in Indonesia, which is based on questionnaire data from a small population of public polytechnic employees, is influenced by the factors in this study but with a significant degree that does not affect the correlation path in the sense that it is negatively related to the punishment factor. We use Pearson Correlation and Exploratory Data Analysis for implementing data science. The value of all Pearson Correlations are between the interval $(0.5 \leq \mathrm{r} \leq 0.9)$. We visualize the relationship between an independent variable (all variables except punishment factor; PF) and punishment to map whether there is no correlation between them, so we omit all variables with no correlation (for example, in Figure 4).

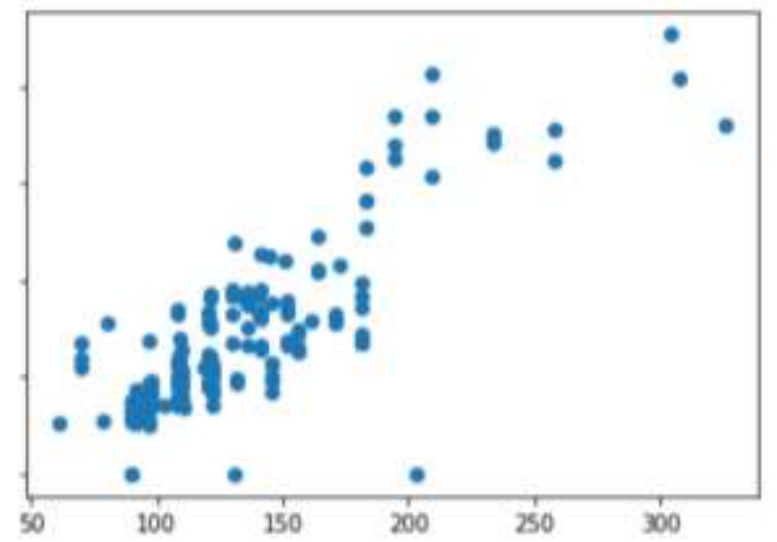

Figure 4. Example correlation between working quantity (Qun) and punishment factor (PF). 
For initiative factor $(\mathrm{InF})$, knowledge factor $(\mathrm{KF})$, quality factor $(\mathrm{QF})$, working quantity factor (Qun), and working overtime factor (Ov) are affected to punishment model of civil servant discipline. Otherwise will be rejected. Data science techniques such as Exploratory Data Analysis (EDA) are performed to support the result analysis of PLS-SEM will improve the model's performance because it rejects uncorrelated variables. All analysis is done and interpreting its findings is as important as describing the quantitative results. With this, supervisors can use quantitative results to evaluate their disciplined or not staff.

\section{CONCLUSION}

The attendance factor, violation factor, initiative factor, team factor, seniority factor, knowledge factor, satisfaction factor, quality factor, innovation factor, quantity factor, adaptation factor, choice factor, and work target factor does not influence the civil servant discipline in Indonesia, respectively, but all of these factors (except the overtime factor) in terms of negatively related to the punishment factor. Related to data science technique, our study shows that initiative factor ( $\mathrm{InF}$ ), knowledge factor $(\mathrm{KF})$, quality factor $(\mathrm{QF})$, working quantity factor (Qun), and working overtime factor (Ov) are affected to punishment model of civil servant discipline.

\section{ACKNOWLEDGMENT}

We thank all parties who have supported the smooth running of this research. We declare that there is no conflict of interest in this study.

\section{REFERENCES}

Ariani, D. W. (2015). Relationship with Supervisor and Co-Workers, Psychological Condition and Employee Engagement in the Workplace. Journal of Business and Management, 4(3), 34-47. https://doi.org/10.12735/jbm.v4i3p34

Arifin, J. (2017). SPSS 24 untuk Penelitian dan Skripsi. Elex Media Komputindo.

Awang, Z., Afthanorhan, A., \& Asri, M. A. M. (2015). Parametric and Non Parametric Approach in Structural Equation Modeling (SEM): The Application of Bootstrapping. Modern Applied Science, 9(9), 58-67. https://doi.org/10.5539/mas.v9n9p58

Creswell, J. W. (2012). Educational Research: Planning, conducting, and evaluating quantitative and qualitative research (4th ed.). Pearson Education.

Division for Public Administration and Development Management. (2005). Malaysia: Public Administration Country Profile (Issue November).

Epstein, J. L., \& Sheldon, S. B. (2002). Present and accounted for: Improving student attendance through family and community involvement. Journal of Educational Research, 95(5), 308-318. https://doi.org/10.1080/00220670209596604

Fehr, E., \& Fischbacher, U. (2004). Third Party Punishment and Social Norms.

Franke, G., \& Sarstedt, M. (2019). Heuristics versus statistics in discriminant validity testing: a comparison of four procedures. Internet Research, 29(3), 430-447.

Kenicer, G. (2008). AN INTRODUCTION TO THE GENUS LATHYRUS L. Curtis's Botanical 
Soelaiman et al.: Modeling the civil servant discipline in Indonesia: partial least square-structural equation modeling approach

Magazine, 25(4), 286-295. https://doi.org/10.1111/j.1467-8748.2008.00632.x

Leguina, A. (2015). A primer on partial least squares structural equation modeling (PLS-SEM). International Journal of Research \& Method in Education, 38(2), 220-221. https://doi.org/10.1080/1743727x.2015.1005806

Maison, Syahrial, Syamsurizal, \& Tanti. (2019). Learning Environment, Students ' Beliefs, and SelfRegulation in Learning Physics: Structural Equation Modeling. Journal of Baltic Science Education, 18(3), 389-403. https://doi.org/10.33225/jbse/19.18.389

Nasution, A. (2016). Government Decentralization Program in Indonesia. In SSRN. https://doi.org/10.2139/ssrn.2877579

Nawanir, G., Lim, K. T., Lee, K. L., Okfalisa, Moshood, T. D., \& Ahmad, A. N. A. (2020). Less for more: The structural effects of lean manufacturing practices on sustainability of manufacturing SMEs in Malaysia. International Journal of Supply Chain Management, 9(2), 961-975.

Pratama, A. P., Ghazali, A., Putranto, N. A. R., Iswari, K. R., Wisesa, A., \& Febriansyah, H. (2015). Civil Servants' Competence in Indonesia: Suggestions for Future Research in the Context of Business. Procedia - Social and Behavioral Sciences, 169, 371-377. https://oi.org/10.1016/j.sbspro.2015.01.322

Presiden Republik Indonesia. (2010). peraturan Pemerintah Republik Indonesia Nomor 53 Tahun 2010. In Peraturan Pemerintah Republik Indonesia (Vol. 2010, Issue 1, pp. 1-95). https://doi.org/10.1017/CBO9781107415324.004

Sarstedt, M., Ringle, C. M., \& Hair, J. F. (2017). Partial Least Squares Structural Equation Modeling. In Handbook of Market Research. Springer International Publishing AG. https://doi.org/10.1007/978-3-319-05542-8_15-1

Sarstedt, M., Ringle, C. M., \& Hair, J. F. (2020). Handbook of Market Research. In Handbook of Market Research (Issue September). https://doi.org/10.1007/978-3-319-05542-8

Sharma, P. N., \& Kim, K. H. (2013). A comparison of PLS and ML bootstrapping techniques in SEM: A Monte Carlo study. In New perspectives in partial least squares and related methods (pp. 201-208). Springer New York. https://doi.org/10.1007/978-1-4614-8283-3 13

Shmueli, G., Sarstedt, M., Hair, J. F., Cheah, J. H., Ting, H., Vaithilingam, S., \& Ringle, C. M. (2019). Predictive model assessment in PLS-SEM: guidelines for using PLSpredict. European Journal of Marketing, 53(11), 2322-2347. https://doi.org/10.1108/EJM-02-2019-0189

Telep, V. G. (2009). Discipline for Young Children. Discipline and Punishment: What is the Difference?.

Tjiptoherijanto, P. (2012). Civil Service Reform in Indonesia : Culture and Institution Issues. Working Paper in Economics and Business, University of Indonesia, II(07).

Ujhelyi, G. (2014). Civil service rules and policy choices: Evidence from US State Governments. American Economic Journal: Economic Policy, 6(2), 338-380. https://doi.org/10.1257/pol.6.2.338 